\title{
Wilms' Tumor in Children: An Overview
}

\author{
Ali Varan \\ Department of Pediatric Oncology, Hacettepe University, Institute of Oncology, Ankara, Turkey
}

\section{Key Words}

Wilms' tumor - Wilms' tumor, children - Wilms' tumor, treatment

\begin{abstract}
Wilms' tumor is the most frequently occurring renal tumor in children and is one of the most treatment-responsive tumors. A tumor-suppressor gene and other genetic abnormalities have been implicated in its etiology. In addition, patients with several congenital anomalies, such as Beckwith-Wiedemann syndrome, WAGR syndrome, and DenysDrash syndrome, have an increased risk of Wilms' tumor. Previously, a three-drug chemotherapy regimen with surgery and radiotherapy was used with patients in all stages. Now, patients with early-stage Wilms' tumor are treated with a two-drug regimen without radiotherapy, whereas those in advanced stages still receive the three-drug regimen and radiotherapy. Two large collaborative groups - the National Wilms' Tumor Study Group (NWTS) in the United States and the International Society of Pediatric Oncology (SIOP) in Europe - are involved in Wilms' tumor management, which differs in some aspects. Multimodality treatment has been used successfully, and in Europe preoperative strategies are used as well. As the survival rate has now reached $90 \%$, the primary objectives of the physician are to perform nephronsparing surgery in selected cases and to reduce the dosage and duration of chemotherapy and radiotherapy in appropriate cases. Other renal tumors occur rarely, but have also been treated successfully in the last decade.
\end{abstract}

Copyright $\odot 2008$ S. Karger AG, Basel

\section{Introduction}

Renal tumors are the fifth most common tumor in children [1], and Wilms' tumor is the most frequently occurring renal tumor in children. The incidence, type, growth rate, and response to treatment of renal tumors in children differ from adult renal cancers. Renal tumors in adults are most likely carcinomas, whereas in children they are of embryonic origin and thus grow rapidly. Renal cell carcinomas, sarcomas, and other tumors of the kidney are extremely rare in children. The other difference from adult tumors is that childhood renal tumors have a better response to treatment.

This article reviews the histopathology, genetics, and changing treatment strategies of Wilms' tumor. It reports the results of our center, as well as those of two large collaborative groups: the National Wilms' Tumor Study Group (NWTS; from North America) and the International Society of Pediatric Oncology (SIOP; from Europe).

\section{Wilms' Tumor}

Wilms' tumor was first reported by Rance in 1814, and it received its name from Max Wilms, a surgeon who identified nephroblastoma as a mixture of three tissues $[2,3]$. Multimodal treatment was first used in treating this tumor, and because it has achieved the best results of any tumor group it has become a treatment model for other tumors. With this successful treatment strategy

\section{KARGER \\ Fax +4161306 1234 \\ E-Mail karger@karger.ch}

www.karger.com
(C) 2008 S. Karger AG, Basel

$1660-2110 / 08 / 1082-0083 \$ 24.50 / 0$

Accessible online at:

www.karger.com/nec
Ali Varan, MD

Department of Pediatric Oncology, Hacettepe University

Institute of Oncology, TR-06100 Ankara (Turkey)

Tel. +90 312305 2990, Fax +90 3123107018

E-Mail hupog@tr.net 
and the creation of cooperative groups in North America and Europe, the survival rate improved from 30 to $90 \%$ between 1930 and 2000.

\section{Epidemiology}

Childhood cancers constitute between 0.5 and $1 \%$ of all cancers. In the USA, the incidence of Wilms' tumor is 7.6 cases per million under 15 years of age [4], and about 500 new cases occur annually. Wilms' tumor represents $5.9 \%$ of all childhood malignant tumors [5]. There is a minor racial difference in the incidence of Wilms' tumors. The Asian population has about half the incidence rate of Western countries, and its rate in the black population is 2.5 times higher $[6,7]$. The incidence of Wilms' tumor in other countries is similar to that in the USA. In Turkey, childhood renal tumors represent $7.1 \%$ of all childhood tumors [8]. The population-based incidence rate in a part of Italy was $4.5 \%$ for Wilms' tumor [9].

Wilms' tumor is seen mostly in children between the ages of 1 and 5 years, and the peak age is 3 . Although adult patients with Wilms' tumor have been reported, it is extremely rare in people older than 15 years of age [10]. The male-female ratio is near 1 , ranging from 0.8 to 0.95 in various studies.

\section{Wilms' Tumor Genetics}

Two frequent genetic abnormalities in Wilms' tumor are the WT1 and WT2 gene deletions:

WT1. The first identified gene in Wilms' tumor, WT1, is responsible for genitourinary development. It is a tumor-suppressor gene located on 11p13 that is expressed in the kidney, gonads, spleen, and mesothelium. It encodes four zinc finger transcriptional factors that have regulatory functions on cell growth, differentiation, and apoptosis. Normal WT1 gene expression is necessary for the maturation of the blastemal cells, and reduced WT1 expression is associated with the stromal predominant Wilms' tumor. Lee and Haber [11] report on the functions of the WT1 gene and its association with connective tissue growth factor and vitamin $\mathrm{D}$ receptors. Its deletion has been shown in WAGR and Denys-Drash syndrome $[12,13]$.

WT2. This gene is located on 11p15 and is found in Beckwith-Wiedemann syndrome [14]. Some functions of this gene are related to insulin-like growth factor 2 (IGF2 ), which encodes embryonal growth factor.

Other Genetic Abnormalities. In addition to IGF-2, $\mathrm{H} 19$ and $\mathrm{p} 57^{\mathrm{Kip} 2}$ are overexpressed or mutated in some patients with Wilms' tumor. p57 ${ }^{\text {Kip2 }}$ encodes cyclin-de- pendent kinase inhibitors and is a putative tumor suppressor $[15,16]$.

The p53 tumor suppressor gene has been found in 75\% of patients with anaplastic histology [17]. This gene regulates cell proliferation and induces apoptosis.

$\beta$-Catenin is a cellular adhesion molecule that promotes overexpression of the c-myc and cyclin D1. $\beta$ Catenin mutation has been detected in $15 \%$ of patients with Wilms' tumor [18]. There is a strong correlation between reduced expression of the WT1 gene and $\beta$-catenin mutation.

Familial Wilms' tumor has been found in $1-2 \%$ of Wilms' tumor cases [19]. Although this tumor does have the WT1 gene, some familial tumors have linkage in the $17 \mathrm{q}$, and this locus has been named FWT1. Some such tumors have demonstrated a 19q anomaly, which has been described as FWT2 [15].

Other chromosomal abnormalities, such as loss of heterozygosity (LOH) of $16 \mathrm{q}, 1 \mathrm{p}$, and $7 \mathrm{p}$, have been identified [20]. This defect has been associated with poor prognosis, relapses, and death and has resulted in a poor outcome in patients with favorable histology Wilms' tumor. In a recent report, a 9-year-old boy with trisomy 18 had Wilms' tumor [21]. In this case, $\mathrm{LOH}$ was demonstrated at isochromosome $7 \mathrm{q}$ and heterozygosity of $16 \mathrm{q}$ was found in addition to trisomy 18 .

\section{Associated Congenital Abnormalities}

Wilms' tumor has been associated with several congenital abnormalities. Children with genitourinary anomalies, such as horseshoe kidney, renal dysplasia, bilateral cystic renal disease, cryptoorchidism, hypospadias, aniridia, and hemihypertrophy, have a higher incidence of Wilms' tumor [22]. In addition, it is a component of the syndromes described below.

Beckwith-Wiedemann Syndrome. This syndrome is associated with macroglossia, visceromegaly, omphalocele, and gigantism. About $4-5 \%$ of patients with this syndrome have Wilms' tumor as well [23]. Although the incidence of bilateral disease has increased, the prognosis is still excellent [23]. The molecular defect is on chromosome 11p15.5 [14]. It is not clear if this defect is the same as is found on the WT2 gene. IGF-2 abnormalities are related to this gene and may be responsible for the development of Wilms' tumor and the Beckwith-Wiedemann syndrome.

WAGR Syndrome. The components of this syndrome are Wilms' tumor, aniridia, genitourinary abnormalities, and mental retardation. Cardiopulmonary problems, head anomalies, neurobehavioral disorders, musculo- 
skeletal defects, and metabolic problems have also been reported [12]. The $11 \mathrm{p} 13$ chromosomal deletion has been identified. The Wilms' tumor risk is $30 \%$ in this syndrome. In a review of 54 patients with WAGR syndrome, 31 had Wilms' tumor and 53 had aniridia [12].

Denys-Drash Syndrome. Male pseudo hermaphroditism, glomerulonephritis, and Wilms' tumor are part of this syndrome. There is also an association with a defect on the WT1 gene [13].

Perlman Syndrome. This syndrome can be associated with Wilms' tumor and includes macrosomia, islet cell hyperplasia, renal hamartomas, and an atypical face shape [24].

\section{Histopathology} 28]:

There are two subclassifications in Wilms' tumor [25-

(1) Classical nephroblastoma: Classical nephroblastoma includes blastemal, epithelial, and stromal components. Sometimes one or two components are predominant, and sometimes they are equally apportioned. The latter type of tumor is classified as a mixed-type or triphasic Wilms' tumor.

(2) Anaplastic Wilms'tumor: If the tumor cells contain multipolar mitotic figures, hyperchromasia with enlarged cells, or nuclei that are three times larger than in adjacent cells, it is classified as an anaplastic Wilms' tumor. This type of tumor constitutes $4-8 \%$ of all cases. It may have a diffuse or focal form; this classification has prognostic importance, as patients with focal anaplasia should be treated with less intensive protocols than those with diffuse anaplasia. Previously, a tumor was classified as focal anaplasia if anaplastic cells were encountered in fewer than $10 \%$ of microscopic fields. This description was revised by Faria et al. [29] in 1996, as follows: In focal anaplasia, anaplastic changes are confined to circumscribed regions within the primary tumor and are surrounded by non-anaplastic tissue. Diffuse anaplasia has the following characteristics: it is found in an extrarenal site, the random biopsy specimen reveals unequivocal anaplasia, the tumor is coupled with extreme nuclear unrest, and there is nuclear atypia elsewhere in the tumor [29].

This classification of focal and diffuse anaplasia has been used in the NWTS (from North America); the other large-scale collaborative group, the SIOP (from Europe), stratifies risk groups according to histopathologic structures. SIOP has analyzed risk for two groups: those pa-
Table 1. Revised SIOP working classification of renal tumors of childhood [30]
A. For pretreated cases

a. Low-risk tumors Mesoblastic nephroma Cystic partially differentiated nephroblastoma Completely necrotic nephroblastoma

b. Intermediate-risk tumors Nephroblastoma-epithelial type Nephroblastoma-stromal type Nephroblastoma-mixed type Nephroblastoma-regressive type Nephroblastoma-focal anaplasia

c. High-risk tumors Nephroblastoma-blastemal type Nephroblastoma-diffuse anaplasia Clear cell sarcoma of the kidney Rhabdoid tumor of the kidney

B. For primary nephrectomy cases

a. Low-risk tumors Mesoblastic nephroma Cystic partially differentiated nephroblastoma

b. Intermediate-risk tumors Non-anaplastic nephroblastoma and its variants Nephroblastoma-focal anaplasia

c. High-risk tumors Nephroblastoma-diffuse anaplasia Clear cell sarcoma of the kidney Rhabdoid tumor of the kidney

tients who have been pretreated and those receiving primary nephrectomy. For pretreated patients, those in the low-risk group had complete necrosis and cystic nephroblastoma; focal anaplasia and other classic nephroblastoma except blastemal type characterized the intermediate-risk group. The high-risk group had blastemal-type, diffuse anaplasia and other variants of Wilms' tumor, such as clear cell sarcoma and rhabdoid tumor. Low-risk patients with primary nephrectomy had the same characteristics as low-risk pretreated patients. Intermediaterisk patients had all variants of classic Wilms' tumor, including the blastemal type, as well as focal anaplasia. High-risk group patients with primary nephrectomy had diffuse anaplasia, rhabdoid tumor of the kidney, and clear cell sarcoma of the kidney. Table 1 shows SIOP risk groups according to histopathology [30].

Tumor classification should determine the choice of treatment protocols. Anaplastic tumors, except for those in stage 1 , should be treated with more intensive protocols than mixed-type tumors [31]. 
Table 2. Staging system for Wilms' tumor

\begin{tabular}{|c|c|c|}
\hline Stage & NWTS & SIOP \\
\hline I & $\begin{array}{l}\text { Tumor is limited to kidney } \\
\text { Totally excised } \\
\text { There is no tumoral involvement in surgical margin } \\
\text { The vessels of renal sinus are not involved } \\
\text { There is no tumoral rupture before or during removal }\end{array}$ & $\begin{array}{l}\text { Tumor is limited to kidney } \\
\text { No tumor cells at the surgical margin } \\
\text { The vessels of renal sinus are not involved } \\
\text { Intrarenal vessels may be involved }\end{array}$ \\
\hline II & $\begin{array}{l}\text { Tumor is outside the kidney } \\
\text { Totally removed } \\
\text { Local spillage and intrarenal vessels could be involved }\end{array}$ & $\begin{array}{l}\text { Tumor extends outside of the kidney } \\
\text { Totally resected but capsule, adjacent tissues, } \\
\text { renal sinus and renal vessels can be involved }\end{array}$ \\
\hline III & $\begin{array}{l}\text { Intra-abdominal tumor } \\
\text { Renal hilus, abdominal lymph nodes are involved } \\
\text { Diffuse spillage } \\
\text { Peritoneal involvement } \\
\text { Thrombus in vena cava }\end{array}$ & $\begin{array}{l}\text { Incomplete resection } \\
\text { Intra-abdominal lymph node involvement but } \\
\quad \text { renal hilus lymph node positivity makes it stage II } \\
\text { Ureteral, peritoneal, and caval involvement } \\
\text { Preoperative or perioperative biopsy or rupture } \\
\text { Peritoneal metastases }\end{array}$ \\
\hline IV & Hematogeneous or distant lymph node metastases & Hematogeneous and extra-abdominal lymph node metastases \\
\hline $\mathrm{V}$ & Bilateral renal tumors & Bilateral renal tumors \\
\hline
\end{tabular}

Nephrogenic Rests. The nephrogenic rest is the precursor lesion of the Wilms' tumor, which sometimes can be mixed with malignancies and include blastemal, stromal, and embryonal nephroblastic tissue. It can be found in the opposite or the same foci in the affected kidney. If located peripherally, it is classified as a perilobar nephrogenic rest; if located deep in the renal lobe, it is an intralobar nephrogenic rest. Nephrogenic rests can regress or stay dormant [26].

\section{Clinical Presentation}

Most patients present with the complaint of abdominal mass. The tumor is often detected by a caregiver while bathing the child. $30 \%$ of patients have hematuria, and $25 \%$ have hypertension $[32,33]$. In addition, patients can suffer from malaise, fever, weight loss, anorexia, or a combination of those symptoms. Varicocele due to compression of the tumor to the spermatic cord can be seen. Some hormones, such as erythropoietin and ACTH, can be secreted in Wilms' tumor. In addition, hypercalcemia and hemorrhagic conditions caused by reduced von Willebrand factor are associated with Wilms' tumor [33]. Physicians also should be alert for other associated findings, such as hemihypertrophy, aniridia, and genitourinary malformations.

\section{Imaging Studies}

Calyceal distortion with renal displacement is the characteristic finding for Wilms' tumor. Before the ultra- sonography (USG) and tomography era, direct radiograph and intravenous urography were used widely. USG and contrast-enhanced tomography (CT) of the abdomen are more effective diagnostic techniques in the staging and follow-up of patients [34-38], as they can detect tumor size, invasion, and tumoral involvement of the lymph nodes. Doppler USG shows vena cava invasion, which is important for determining the preoperative treatment strategy. USG or CT shows other parenchymal organ metastasis, such as to the liver, but not whether subpleural or parenchymal nodules are true metastatic nodules or are related to infections or postoperative changes. However, that question is not relevant to prognosis. Because the presence or absence of lung nodules does not affect the treatment plan in the early stages, a lung CT is not necessary [39]. The survival of the patients with metastasis from the right kidney is worse than the survival of those with metastasis from the left kidney [40].

\section{Staging}

Two large groups are involved in Wilms' tumor management: the NWTS (from North America) and the SIOP (from Europe). They use similar staging systems with only minor differences. SIOP gives preoperative chemotherapy and then does staging after preoperative treatment and surgery. The NWTS group treats patients with surgery at the time of diagnosis, and then they are staged. The staging system of these two groups is shown in table $2[30,41]$. 


\section{Treatment}

Multimodality treatment has been used to treat Wilms' tumor successfully. Its components are described below.

\section{Surgery}

Surgery is the cornerstone of treatment. Transperitoneal approaches are used [42], as the flank incision is not suitable for Wilms' tumor. All abdominal organs, lymphadenopathies, and the opposite kidney should be investigated carefully. Ligation of both the renal artery and vein is preferable before performing radical nephrectomy. Surgeons must take care to prevent tumor spillage, which has a negative effect on prognosis [43]. Wilms' tumor is an encapsulated tumor, and as much as possible, it should be removed with no capsular perforation. In SIOP studies, surgery is performed after 1 month of chemotherapy treatment.

The UKCCSG (United Kingdom Children Cancer Study Group) has examined the accuracy of percutaneous needle biopsy for initial diagnosis and found that $4 \%$ of the samples were not diagnostic but that $85 \%$ of the samples confirmed the diagnosis of Wilms' tumor. The authors therefore recommend needle biopsy at the time of diagnosis. Patients in this large series had minimal complications and no increased risk of local recurrence or upstaging [44].

Another study looked at the results of nephron-sparing surgery in stage I patients who had $50 \%$ of the kidney preservable [45]. They suggested that this technique should be used in selective cases. The role of nephronsparing surgery in other types of patients has not yet been clarified [46].

\section{Chemotherapy}

NWTS: The NWTS group has investigated five protocols [47-49]. In NWTS 1 (1969-73) the vincristine + dactinomycin combination was more effective than either drug alone in stage II and III patients [50]. NWTS 2 was conducted between 1974 and 1978. It found that a treatment duration of either 6 or 15 months was equally effective in stage I patients, and, after these results were published, treatment duration in protocols was shortened. Addition of adriamycin to the chemotherapy protocols improved the survival rate in patients with Wilms' tumor [49].

In NWTS 3, stage I patients were treated successfully with a two-drug regimen for 10 weeks [51]. For stage II patients, there was no significant difference in outcome between the RT or no RT arms, nor between the arm without adriamycin. Stage IV patients received no benefit from the addition of cyclophosphamide to the three-drug regimen. Different radiotherapy doses $(1,000$ vs. 2,000 cGy) also had no effect on survival. After this report, most treatment centers decreased the radiotherapy doses they used to treat Wilms' tumor. NWTS 4 also demonstrated that pulse-intensive actinomycin-D (single injection of $45 \mu \mathrm{g} / \mathrm{kg}$ ) was as potent as the long-term injection dose (15 $\mu \mathrm{g} / \mathrm{kg} /$ day for 5 days) [52]. The addition of adriamycin had a strong effect on survival in patients with stage III in NWTS 3-4 studies [53].

NWTS 5 investigated whether stage I patients actually benefited from chemotherapy. Without chemotherapy, the 2-year overall survival was $100 \%$, but relapse-free survival was $86 \%$. Therefore, this arm has been closed. $\mathrm{LOH}$ at chromosome 1 and $16 \mathrm{q}$ has been shown to be a poor prognostic factor in this study [20].

SIOP Studies [54, 55]: The SIOP 1 study compared the effectiveness of prenephrectomy irradiation versus immediate surgery and found that the two arms had the same overall survival rates. The SIOP 2 study found that preoperative treatment resulted in a decreased tumor rupture rate. In the SIOP 5 study, preoperative chemotherapy was substituted for preoperative radiotherapy. The SIOP 6 study showed that 17 weeks of chemotherapy treatment was as effective as 38 weeks of treatment for patients with stage I disease. Relapse risk increased in stage II lymph-node-negative patients who did not receive radiotherapy. The addition of epirubicin was planned in this group of patients. Also, radiotherapy doses were decreased from 30 to 15 Gy. The aim of the SIOP 9 protocol was to determine how the duration of preoperative chemotherapy affected survival. There was no significant difference in survival between 4 and 8 weeks of preoperative treatment [56]. SIOP 93-01 studies have aimed to reduce treatment duration. Stage I patients were treated postoperatively for 4 weeks, whereas patients in other stages received 27 weeks of postoperative treatment. In this randomized study, there was no significant difference in terms of event-free survival rates [57], although patients with progressive disease during preoperative chemotherapy had poorer survival than the others [58].

UKCCSG Protocols: This group treated patients with the postoperative chemotherapy regimen used by the NWTS group. Patients with tumors that the surgeons thought were unresectable were given preoperative chemotherapy [59-61]. In patients with stage I, vincristine alone was as effective as vincristine and actinomycin-D. 
In the first study, the duration of the vincristine regimen in stage I was 6 months [59]. This duration was shortened to 10 weeks in the second study [61]. This recommendation was limited to patients younger than 4 years. The group did not recommend using single-agent vincristine in older patients. Treatment results with stage IV patients were not as good as those obtained by the NWTS group.

Other single-center or collaborative studies have been published in different centers [62-64].

\section{Radiotherapy}

In the early years, all stage I and II patients were treated with flank irradiation, and those with stage III and IV were treated with whole abdominal radiotherapy. Since 1975, patients with favorable histology stage I no longer receive radiotherapy. Stage III and IV patients and those with otherwise local stage I and II receive flank irradiation instead of whole abdomen radiotherapy. Dosages were reduced to 2,700 cGy and later to 1,000 cGy depending on the histology and stage, rather than the age of the patient $[65,66]$. Whole lung irradiation of $12 \mathrm{~Gy}$ was generally given in patients with metastatic lung disease with post-stamp boost (or boosts) of $10 \mathrm{~Gy}$ whenever possible [41]. Since about 1990, patients with stage III and IV are treated with radiotherapy delivered to the tumor bed in $10-$ Gy dosages. Lung irradiation is used only in patients with residual or resistant disease after undergoing induction chemotherapy.

\section{Treatment of Anaplastic Wilms' Tumor}

All patients except stage I should be treated with intensive chemotherapy and radiotherapy. Vincristine + actinomycin-D + adriamycin and cyclophosphamide are used in this type of tumor [67]. In the last NWTS study, patients with stage I disease were treated with vincristine + actinomycin-D for 18 weeks and achieved good results. Patients with diffuse anaplastic stage II-IV disease were treated with vincristine + cyclophosphamide + actinomycin-D + etoposide for 24 weeks. The results in this group were unsatisfactory. The authors suggested that new drugs, such as carboplatin, should be tried in patients with anaplastic Wilms' tumor [68].

\section{Treatment of Bilateral Wilms' Tumor}

The principal treatment of bilateral Wilms' tumor is nephrectomy of the larger tumor after preoperative treatment or through immediate surgery $[69,70]$. After induction chemotherapy, the smaller tumor should be removed by partial nephrectomy. Some authors suggested that limited radiotherapy could be applied. Whatever the treatment, salvage of the kidney should be the goal.

\section{Prognosis}

The prognosis of patients with Wilms' tumor is the most favorable of all solid tumors, and an $85 \%$ survival rate in all patients has been reached. The survival rate is $95 \%$ in patients in stages I and II, $75-80 \%$ in stage III patients, and $65-75 \%$ in patients with stage IV. Only $15 \%$ of patients with favorable histology have recurrent disease, compared to a rate of $50 \%$ in those with anaplastic histology. The most common sites of recurrence are the lungs, pleura, tumor bed, and the liver. Among all patients with Wilms' tumor, those with liver involvement have a poorer prognosis than those with lung metastasis $[40,71]$.

\section{Future Perspectives in Wilms' Tumor}

Partial nephrectomy or nephron-sparing surgery should be done in selected patients. Low-risk patients should receive fewer chemotherapeutic agents and at lower cumulative doses. Vincristine alone or no treatment should be used in these patients. Trials to further reduce radiotherapy doses or omit radiotherapy in selected cases may be undertaken.
References

\footnotetext{
Jemal A, Siegel R, Ward E, Murray T, Xu J, Smigal C, Thun MJ: Cancer statistics 2006. CA Cancer J Clin 2006;56:106-130.

2 Rance TF: Case of fungus haematodes of the kidnies. Med Phys J 1814;32:19-25.

3 Wilms M: Die Mischgeschwülste der Niere. Leipzig, A Georgi, 1899, pp 1-90.
}

\footnotetext{
4 Bernstein L, Linet M, Smith MA, Olshan AF: Renal tumors; in Ries LAG, Smith MA, Gurney JG (eds): Cancer Incidence and Survival among Children and Adolescents: United States SEER Program 1975-1995. National Cancer Institute, SEER Program, Bethesda, NIH Publ No 99-4649, 1999, pp 79-90.
} 
5 Gurney JG, Bondy ML: Epidemiology of childhood cancer; in Pizzo PA, Poplack DG (eds): Principles and Practice of Pediatric Oncology, ed 5. Philadelphia, Lippincott Williams \& Wilkins, 2006, pp 1-13.

$\checkmark 6$ Kramer S, Meadows AT, Jarrett P: Racial variation in incidence of Wilms' tumor: relationship to congenital anomalies. Med Pediatr Oncol 1984;12:401-405.

$\checkmark 7$ Breslow NE, Langholz B: Childhood cancer incidence: geographical and temporal variations. Int J Cancer 1983;32:703-716.

8 Kutluk T: First national pediatric cancer registry in Turkey: a Turkish Pediatric Oncology Group (TPOG) study. Pediatr Blood Cancer 2004;43:452.

$\checkmark 9$ Dama E, Pastore G, Luisa Mosso M, Maria Maule M, Zuccolo L, Magnani C, Merletti F: Time trends and prognostic factors for survival from childhood cancer: a report from the childhood cancer registry of Piedmont (Italy). Eur J Pediatr 2006;165:240-249.

-10 Terenziani M, Spreafico F, Collini P, Piva L, Perotti D, Podda M, Gandola L, Massimino M, Cereda S, Cefalo G, Luksch R, Casanova M, Ferrari A, Polastri D, Valagussa P, Fossati-Bellani F: Adult Wilms' tumor: a monoinstitutional experience and review of the literature. Cancer 2004;101:289-293.

$\checkmark 11$ Lee SB, Haber DA: Wilms' tumor and the WT1 gene. Exp Cell Res 2001;264:74-99.

$\checkmark 12$ Fischbach BV, Trout KL, Lewis J, Luis CA, Sika M: WAGR syndrome: a clinical review of 54 cases. Pediatrics 2005;116:984-988.

13 Büyükpamukçu M, Kutluk T, Büyükpamukçu N, Sarıalioğlu F, Akyüz C: Renal tumors with pseudohermaphroditism and glomerular disease. Acta Oncol 1992;31: 745-748.

-14 Niemitz EL, Feinberg AP, Brandenburg SA, Grundy PE, DeBaun MR: Children with idiopathic hemihypertrophy and BeckwithWiedemann syndrome have different constitutional epigenotypes associated with Wilms' tumor. Am J Hum Genet 2005;77: 887-891.

15 Dome JS, Coppes MJ: Recent advances in Wilms' tumor genetics. Curr Opin Pediatr 2002; $14: 5-11$

-16 Matsuoka S, Edwards MC, Bai C, Parker S, Zhang P, Baldini A, Harper JW, Elledge SJ: p57 $7^{\mathrm{KIP} 2}$, a structurally distinct member of the $\mathrm{p} 21^{\mathrm{CIP} 1} \mathrm{Cdk}$ inhibitor family, is a candidate tumor suppressor gene. Genes Dev 1995;9:650-662.

-17 Bardeesy N, Falkoff D, Petruzzi MJ, Nowak N, Zabel B, Adam M, Aguiar MC, Grundy P, Shows T, Pelletier J: Anaplastic Wilms' tumor, a subtype displaying poor prognosis, harbours p53 gene mutations. Nat Genet 1994;7:91-97.

18 Maiti S, Alam R, Amos CI, Huff V: Frequent association of $\beta$-catenin and WT1 mutations in Wilms' tumors: Cancer Res 2000;60: 6288-6292.

19 Ruteshouser EC, Huff V: Familial Wilms' tumor. Am J Med Genet 2004;129C:29-34.
20 Grundy PE, Breslow NE, Li S, Perlman E, Beckwith JB, Ritchey ML, Shamberger RC, Haase GM, D’Angio GJ, Donaldson $M$, Coppes MJ, Malogolowkin M, Shearer P, Thomas PRM, Macklis R, Tomlinson G, Huff V, Green DM: Loss of heterozygosity for chromosomes $1 \mathrm{p}$ and $16 \mathrm{q}$ is an adverse prognostic factor in favorable-histology Wilms' tumor: a report from the National Wilms' Tumor Study Group. J Clin Oncol 2005;23:7312-7321.

-21 Anderson CE, Punnett HH, Huff V, de Chadarévian JP: Characterization of a Wilms' tumor in a 9-year-old girl with trisomy 18 . Am J Med Genet 2003;121A:52-55.

22 Pendergrass TW: Congenital anomalies in children with Wilms' tumor. Cancer 1976; 37:403-408.

23 Porteus MH, Narkool P, Neuberg D, Guthrie K, Breslow N, Green DM, Diller L: Characteristics and outcome of children with Beckwith-Wiedemann syndrome and Wilms' tumor: a report from the National Wilms Tumor Study Group. J Clin Oncol 2000;18: 2026-2031.

24 Greenberg F, Stein F, Gresik MV, Finegold MJ, Carpenter RJ, Riccardi VM, Beaudet AL: The Perlman familial nephroblastomatosis syndrome. Am J Med Genet 1986;24:101110.

25 Beckwith JB: Wilms' tumor and other renal tumors of childhood: a selective review from the National Wilms' Tumor Study Pathology Center. Hum Pathol 1983;14:481-492.

26 Beckwith JB, Kiviat NB, Bonadio JF: Nephrogenic rests, nephroblastomatosis, and the pathogenesis of Wilms' tumor. Pediatr $\mathrm{Pa}$ thol 1990;10:1-36.

27 Beckwith JB, Palmer NF: Histopathology and prognosis of Wilms' tumor: results from the first National Wilms' Tumor Study. Cancer 1978;41:1937-1948.

28 Beckwith JB: National Wilms' Tumor Study: an update for pathologists. Pediatr Dev Pathol 1998;41:79-84.

-29 Faria P, Beckwith JB, Mishra K, Zuppan C Weeks DA, Breslow N, Daniel G: Focal versus diffuse anaplasia in Wilms' tumor - New definitions with prognostic significance: a report from the National Wilms' Tumor Study Group. Am J Surg Pathol 1996;20: 909-920.

30 Vujanić GM, Sandstedt B, Harms D, Kelsey A, Leuschner I, de Kraker J, on behalf of the SIOP Nephroblastoma Scientific Committee: Revised International Society of Paediatric Oncology (SIOP) working classification of renal tumors of childhood. Med Pediatr Oncol 2002;38:79-82.

31 Perlman EJ: Pediatric renal tumors: practical updates for the pathologist. Pediatr Dev Pathol 2005;8:320-338.

32 Green DM: Diagnosis and Management of Malignant Solid Tumors in Infants and Children. Boston, Nijhoff, 1985, pp 1-552.
33 Coppes MJ: Serum biological markers and paraneoplastic syndromes in Wilms' tumor. Med Pediatr Oncol 1993;21:213-221.

34 Damgaard-Pedersen K: CT and IVU in the diagnosis of Wilms' tumor. Pediatr Radiol 1980;9:207-211.

35 Donaldson JS, Shkolnik A: Pediatric renal masses. Semin Roentgenol 1988;23:194204

36 Cohen MD: Genitourinary tumors (imaging of the primary tumor); in Cohen MD (ed): Imaging of Children with Cancer, ed 1. St Louis, Mosby-Year Book, 1992, pp 60-74.

37 Cohen MD: Staging of Wilms' tumor. Clin Radiol 1993;47:77-81.

38 D’Angio GJ, Rosenberg H, Sharples K, Kelalis P, Breslow N, Green DM: Position paper: Imaging methods for primary renal tumors of childhood: costs versus benefits. Med Pediatr Oncol 1993;21:205-212.

39 Meisel JA, Guthrie KA, Breslow NE, Donaldson SS, Green DM: Significance and management of computed tomography detected pulmonary nodules: a report from the National Wilms' Tumor Study Group. Int J Radiat Oncol Biol Phys 1999;44:579-585.

40 Varan A, Büyükpamukçu N, Çağlar M, Köksal Y, Yalçın B, Akyüz C, Kutluk T, Büyükpamukçu M: Prognostic significance of metastatic site at diagnosis in Wilms' tumor: results from a single center. J Pediatr Hematol Oncol 2005;27:188-191.

41 Kalapurakal JA, Dome JS, Perlman EJ, Malogolowkin M, Haase GM, Grundy P, Coppes MJ: Management of Wilms' tumor: current practice and future goals. Lancet Oncol 2004;5:37-46.

42 Kim S, Chung DH: Pediatric solid malignancies: neuroblastoma and Wilms' tumor. Surg Clin North Am 2006;86:469-487.

43 National Wilms' Tumor Study Committee: Wilms' tumor: status report, 1990. J Clin Oncol 1991;9:877-887.

44 Vujanić GM, Kelsey A, Mitchell C, Shannon RS, Gornall P: The role of biopsy in the diagnosis of renal tumors of childhood: results of the UKCCSG Wilms' tumor study 3. Med Pediatr Oncol 2003;40:18-22.

45 Cozzi DA, Schiavetti A, Morini F, Castello MA, Cozzi F: Nephron-sparing surgery for unilateral primary renal tumor in children. J Pediatr Surg 2001;36:362-365.

46 Wu HY, Snyder HM, D’Angio GJ: Wilms' tumor management. Curr Opin Urol 2005;15: 273-276.

47 Green DM, Thomas PRM, Shochat S: The treatment of Wilms' tumor: results of the National Wilms' Tumor Studies. Hematol Oncol Clin North Am 1995;9:1267-1274.

48 Green DM: The treatment of stages I-IV favorable histology Wilms' tumor. J Clin Oncol 2004;22:1366-1372.

49 Metzger ML, Dome JS: Current therapy for Wilms' tumor. Oncologist 2005;10:815826. 
-50 D’Angio GJ, Evans AE, Breslow N, Beckwith B, Bishop H, Feigl P, Goodwin W, Leape LL, Sinks LF, Sutow W, Tefft M, Wolff J: The treatment of Wilms' tumor: results of the National Wilms' Tumor Study. Cancer 1976; 38:633-646.

- 51 D’Angio GJ, Breslow N, Beckwith JB, Evans A, Baum E, deLorimier A, Fernbach D, Hrabovsky E, Jones B, Kelalis P, Othersen B, Tefft M, Thomas RM: Treatment of Wilms' tumor: results of the Third National Wilms' Tumor Study. Cancer 1989;64:349-360.

- 52 Green DM, Breslow NE, Beckwith J, Finklestein JZ, Grundy PE, Thomas PRM, Kim T, Shochat SJ, Haase GM, Ritchey ML, Kelalis PP, D'Angio GJ: Comparison between single-dose and divided-dose administration of dactinomycin and doxorubicin for patients with Wilms' tumor: a report from the $\mathrm{Na}$ tional Wilms' Tumor Study Group. J Clin Oncol 1998;16:237-245.

- 53 Breslow NE, Ou SS, Beckwith JB, Haase GM, Kalapurakal JA, Ritchey ML, Shamberger RC, Thomas PRM, D'Angio GJ, Green DM: Doxorubicin for favorable histology, stage II-III Wilms' tumor: results from the $\mathrm{Na}$ tional Wilms' Tumor Studies. Cancer 2004; 101:1072-1080.

54 De Kraker J, Weitzman S, Voute PA: Preoperative strategies in the management of Wilms' tumor. Hematol Oncol Clin North Am 1995;9:1275-1285.

- 55 Suryanarayan K, Marina N: Wilms' tumor: optimal treatment strategies. Drugs 1998;56: 597-605.

- 56 Tournade MF, Com-Nougué C, de Kraker J, Ludwig R, Rey A, Burgers JMB, Sandstedt B, Godzinski J, Carli M, Potter R, Zucker JM, for the International Society of Pediatric Oncology Nephroblastoma Trial and Study Committee: Optimal duration of preoperative therapy in unilateral and non-metastatic Wilms' tumor in children older than 6 months: results of the Ninth International Society of Pediatric Oncology Wilms' Tumor Trial and Study. J Clin Oncol 2001;19: 488-500.

57 De Kraker J, van Tinteren H, Pein F, Sandstedt B, Godzinski J, Tournade MF, for the International Society of Pediatric Oncology Nephroblastoma Trial Committee: Reduction of postoperative chemotherapy in children with stage I intermediate-risk and anaplastic Wilms' tumour (SIOP 93-01 trial): a randomised controlled trial. Lancet 2004;364:1229-1235.
58 Øra I, van Tinteren H, Bergeron C, de Kraker J, on behalf of the SIOP Nephroblastoma Study Committee: Progression of localised Wilms' tumour during preoperative chemotherapy is an independent prognostic factor: a report from the SIOP 93-01 nephroblastoma trial and study. Eur J Cancer 2007;43: 131-136.

59 Pritchard J, Imeson J, Barnes J, Cotterill S, Gough D, Marsden HB, Morris-Jones P, Pearson D: Results of the United Kingdom Children's Cancer Study Group first Wilms' tumor study. J Clin Oncol 1995;13:124-133.

60 Grundy RG, Hutton C, Middleton H, Imeson J, Pritchard J, Kelsey A, Marsden HB, Vujanic GM, Taylor RE, for the UKCCSG: Outcome of patients with stage III or inoperable WT treated on the second United Kingdom WT Protocol (UKWT2); a United Kingdom Children's Cancer Study Group (UKCCSG) study. Pediatr Blood Cancer 2004;42:311319.

61 Mitchell C, Pritchard Jones K, Shannon R, Hutton C, Stevens S, Machin D, Imeson J, Kelsey A, Vujanic GM, Gornall P, Walker J, Taylor R, Sartori P, Hale J, Levitt G, Messahael B, Middleton H, Grundy R, Pritchard J, for the United Kingdom Cancer Study Group: Immediate nephrectomy versus preoperative chemotherapy in the management of non-metastatic Wilms' tumor: results of a randomised trial (UKW3) by the UK Children's Cancer Study Group. Eur J Cancer 2006;42:2554-2562.

-62 Kutluk T, Varan A, Büyükpamukçu N, Atahan L, Çağlar M, Akyüz C, Büyükpamukçu M: Improved survival of children with Wilms' tumor. J Pediatr Hematol Oncol 2006;28:423-426.

63 Yildiz I, Yüksel L, Özkan A, Apak H, Celkan T, Danismend N, Büyükünal C, Söylet Y, Sarimurat N, Dervisoglu S, Aksoy F, Atkovar G, Okkan S: Multidisciplinary approach to Wilms' tumor: 18 years of experience. Jpn J Clin Oncol 2000;30:17-20.

64 Akyüz C, Yalcin B, Yildiz I, Hazar V, Akici F, Tokuc G, Buyukpamukcu N, Caglar M, Atahan L, Buyukunal C, Dervisoglu S, Atkovar G, Melikoglu M, Karpuzoglu G, Akbiyik N, Sander S, Darendeliler E, Kuyumcu U, Özseke N, Yörük A, Ayan I, Yaris N, Oguz A, Dagdeviren A, Sarialioglu F, Duzovali Ö, Tanyel A, Buyukpamukcu M: Treatment of Wilms' tumor: a report from the Turkish Pediatric Oncology Group. Pediatr Blood Cancer 2004;43:422.
65 Breslow NE, Beckwith JB, Haase GM, Kalapurakal JA, Ritrchey ML, Shamberger RC, Thomas PRM, D’Angio GJ, Green DM: Radiation therapy for favorable histology Wilms' tumor: prevention of flank recurrence did not improve survival on National Wilms' Tumor Studies 3 and 4. Int J Radiat Oncol Biol Phys 2006;65:203-209.

66 Flentje M, Weirich A, Graf N, Pötter R, Zimmerman $\mathrm{H}$, Ludwig R: Abdominal irradiation in unilateral nephroblastoma and its impact on local control and survival. Int J Radiat Oncol Biol Phys 1998;40:163-169.

67 Green DM, Beckwith JB, Breslow NE, Faria P, Moksness J, Finklestein JZ, Grundy P, Thomas PRM, Kim T, Shochat S, Haase G, Ritchey M, Kelalis P, D’Angio GJ: Treatment of children with stages II to IV anaplastic Wilms' tumor: a report from the National Wilms' Tumor Study Group. J Clin Oncol 1994;12:2126-2131.

68 Dome JS, Cotton CA, Perlman EJ, Breslow NE, Kalapurakal JA, Ritchey ML, Grundy PE, Malogolowkin M, Beckwith JB, Shamberger RC, Haase GM, Coppes MJ, Coccia P, Kletzel M, Weetman RM, Donaldson M, Macklis RM, Green DM: Treatment of anaplastic histology Wilms' tumor: results from the fifth National Wilms' Tumor Study. J Clin Oncol 2006;24:2352-2358.

69 Shearer P, Parham DM, Fontanesi J, Kumar M, Lobe TE, Fairclough D, Douglass EC, Wilimas J: Bilateral Wilms' tumor. Review of outcome, associated abnormalities, and late effects in 36 patients treated at a single institution. Cancer 1993;72:1422-1426.

70 Shamberger RC, Haase GM, Argani P, Perlman EJ, Cotton CA, Takashima J, Green DM, Ritchey ML: Bilateral Wilms' tumors with progressive or non-responsive disease. J Pediatr Surg 2006;41:652-657.

-71 Szavay P, Luithle T, Garf N, Furtwangler R, Fuchs J: Primary hepatic metastases in nephroblastoma - a report of the SIOP/ GPOH study. J Pediatr Surg 2006;41:168172. 